\title{
THE DESIGN AND DEVELOPMENT OF MobiEko: A MOBILE EDUCATIONAL APP FOR MICROECONOMICS MODULE
}

\author{
Mohamad Siri Muslimin, Norazah Mohd Nordin, \\ Ahmad Zamri Mansor \& Melor Md Yunus
}

\author{
Faculty of Education \\ Universiti Kebangsaan Malaysia, Malaysia
}

Corresponding author:msiri@siswa.ukm.edu.my

\begin{abstract}
Purpose - The purpose of this study is to presents the steps taken to produce a mobile learning application framework to learn Microeconomics for which is named "MobiEko Apps". Mobile learning application is utilized because the framework enables seamless access between all the involved actors. The design and development of an application prototype in this study are based on the ADDIE instructional design model.

Methodology - This study was conducted to develop an educational mobile application for Microeconomics by eliciting learning content and evaluating learners' satisfaction after the use of app. The design and development of an application prototype in this study are based on the ADDIE instructional design model (Analysis, Design, Development, Implementation, and Evaluation). This approach provides educators with useful, clearly defined stages for the effective implementation of instruction. Five stages comprise the framework, each with its own distinct purpose and function in the progression of instructional design. In this study, Prototype applications that want to produce is an education material in the form of mobile application based on Android platform to support teaching and learning activities in the classroom.
\end{abstract}

Findings - A systematic research framework using ADDIE (Analyze, Design, Develop, Implement, and Evaluate) approach is proposed to produce mobile application (MobiEko app) by dividing the content of the application into four main activities namely as 
learning menu, learning activities, assessment activities and support activities. The findings also showed that students were satisfied of the presentation design, visual, navigation and accessibility of 'MobiEko' application. Additionally, Mobile educational application (MobiEko) successfully performed as a knowledge transfer channel to help students and learners understand better the concepts and course contents as well as facilitated educators and students with better or more convenient ways in their teaching and learning activities.

Significance - The present study has great significance to explore the roles of self-directed learning through mobile application to enhance the student's knowledge through the development of an educational mobile application. It is expected to encourage students to carry out self-study while improving the quality of teaching and learning activities in line with the 21 st century learning. The education mobile application envisioned to be applied in blended learning scenario to support instructors and students in teaching and learning, leveraging on the affordance and ownership of mobile devices as well as to facilitate the learning of Microeconomics courses on mobile devices.

Keywords: Mobile learning, ADDIE, design and development, instructional design model \& microeconomics, mobile educational application.

\section{INTRODUCTION}

Decades ago, education has experienced transformation and grown from learning merely in the classroom to distance learning and the virtual classroom. Likewise, knowledge acquisition is no longer limited to the classroom. Hence, the notion of integrating technology in education is in line with the Ministry of Higher Education's (MOHE) aspirations to put forth information and communications technology (ICT) as a central concept in transforming the educational system. In Higher Education Malaysia (HEIs) in Malaysia, the delivery mechanism for a course is typically the face-to-face classroom set-up as well as blended with standardized Learning Management System (LMS) as a platform (Baharom \& Hussain, 2013). To embrace the potential of the mobile devices, there needs to 
be a study on the prospect of providing another platform for higher education students to ensure that their learning is supported outside the classroom. In the 21st century, exploration of the capabilities and implications of Mobile Learning has increased as a result of mobile technology advances, in which desktops are being replaced by tablets, software by apps, and mobile phone by smartphones.

Observing the potential of the mobile phone as an additional tool for learning, many researchers have embarked on this study, which aims to investigate the possibilities of mobile application development for utilizing the features and activities to provide supplementary learning activities. Irwan, Norazah, Rosseni, Arif, \& Ridzwan, (2015) have stressed the important role of planning and need analysis study for a design and development process of mobile application in the context of Technical and Vocational Education and Training (TVET) education. A study conducted with 31 Islamic Education teachers and 31 students in secondary schools showed that the mobile application developed have great potential for integration into the Islamic Education subject (Nawi, Hamzah, Akmal, \& Sattai, 2014), whereas another study on the design and use of educational apps aligns with known processes of children's learning and development also showed that the mobile applications may promote active, engaged, meaningful, and socially interactive learning (Hirsh-Pasek et al., 2015).

Not only students but also educators should be fortified to vary their educational approaches and to avoid limiting their practice to only traditional methods of instruction. In the context of Economics teaching and learning process, most teachers are stuck on traditional methods that have been in practice for many years. A specific example would be the chalk-and-talk method, which is defined as a traditional method of education in which the teacher addresses the students and uses the blackboard to provide examples or illustrations (Ding \& Li, 2011; Joshi \& Marri, 2006). Many students who take economics classes get bored and uninterested in the material taught because of these outdated teaching methods. If teachers could use more effective methods in the economics courses they teach, their students would be able to better comprehend the information. The issue is that academics cannot teach the same way they have trained a decade ago but need to make the paradigm shift to accommodate the diverse Mobile-generation student population in their teaching styles. 
The above-presented review of previous research indicates that there is a need for specifically designed educational mobile applications that combine motivational aspects with appropriate curricular objectives and content. Furthermore, empirical research on the learning effectiveness of computer games in relation to concrete curricular objectives is necessary. The concept of 'anytime' and 'anyplace' of mobile learning should be designed in enhancing the pedagogical activities in delivering lessons to capture students' attention and enthusiasm for educational purposes (Bidin \& Ziden, 2013). However, yet there is very limited empirical research done to understand the development practices of such mobile apps been undertaken for concrete educational purposes, and, thus, more research evidence is needed (Embi \& Nordin, 2013; Syer, 2013; Tajudeen, Basha, Fakomogbon, \& Mukthar, 2011; Wang \& Shen, 2012; M. Zhang, Trussell, Tillman, \& An, 2015). The research conducted so far on the potential educational benefits of mobile application has in most cases mainly focused on the investigation of motivations, perceptions, and attitudes of students toward Mobile Learning (Hwang \& Tsai, 2011).

The aim of the present study was the design and development of a mobile educational application for learning Microeconomics concepts, that form part of the Economic education curriculum, and its evaluation both regarding its learning effectiveness and acceptance in relation to a presentation, visual, navigation and accessibility of mobile app design.

\section{SIGNIFICANCE OF STUDY}

Mobile learning products with new learning content and apps creating a lot of anticipation in the learning community these days. The emergence of the digital native generation, that is children who grow up using and relating to modern ICTs, provides a strong motive for research of learning with mobile devices to understand and achieve the potential educational benefits of m-learning (Prensky, 2001, 2005). Mobile devices such as smartphones, iPad, tablet, and netbook are generally used in this technological savvy environment. Certainly, the mobile devices have established its significant status in this technology era because the mobile capability to fulfil and meet the needs of the society. The use of mobile devices has witnessed 
the changes of a landscape in the classroom, encourage teachers and students to participate actively so that educational process more attractive, interactive and lifelong learning (Embi \& Nordin, 2013; Nordin, Amin, \& Yunus, 2010). The rapid development of information, communication \& technology (ICT) also provided an opportunity for educators to incorporate the use of appropriate devices and applications in teaching and learning processes. Therefore, the scenario and pedagogy in teaching and learning process should be redesigned in order to meet the needs of the 21 st century education.

\section{DESCRIPTION OF THE MOBILE EDUCATIONAL APPLICATION (MobiEko App)}

A mobile application, most commonly referred to as an app, is a type of application software designed to run on a mobile device, such as a smartphone or tablet computer. Mobile applications frequently serve to provide users with similar services to those accessed on PCs (Hsu \& Ching, 2013). Apps are generally small, individual software units with limited function. 'MobiEko' is an educational application in the form of a mobile app. The application was designed and developed by the researcher in an effort to make teaching and learning of Microeconomics concepts more interesting and enjoyable for teachers and students, and to bridge the gap between formal pedagogic education and informal forms of education, with which students come into contact outside.

The application aims at introducing Polytechnics students to basic concepts relevant to the Microeconomics curriculum such as demand and supply theory, elasticity and production as well as market equilibrium output level determination and market price structure. The learning objectives of the application are that students understand: a) apply effectively the knowledge of basic theories in the field of microeconomics, b) use the knowledge of microeconomics theories to solve the business, and c) explain clearly the impact of economic changes towards market equilibrium. MobiEko app can be used either for self-learning by the students or as a teaching aid for the Microeconomics instructor, who can prompt the students to use it and then assume the role of a 'guide on the side'. The approach adopted in the design of the application was that of active, exploratory learning within a multimedia environment that combines access to 
hypermedia learning material in the form of HTML pages, web, and interactive games. Through navigation within the environment of the application, the student has the opportunity to think and reflect about the concepts presented in the learning material and to test his/her understanding of these concepts through the engaging and amusing activity of mobile application. The design of the instructional materials should be based on principles of instructional design theories, learning theories, model, and media selection for the purpose of instruction.(Rio Sumarni Shariffudin, 2007).

Designing for wireless mobile devices is complex and challenging. There are no proposed guidelines for designing an effective and usable mobile application that is scientifically proved (Fetaji, 2008). However, this study partly used the design guidelines for desktop applications and based on the design of the interface on the "eight golden rules of interface design" (Elias, 2011): (1) equitable use, (2). flexible use, (3) simple and intuitive, (4) perceptible information, (5) tolerance for error, (6) low physical and technical effort, (7) community of learners and support, and (8) instructional climate. Although not specifically developed for mobile learning environments, these are equally relevant to them. The relevance of almost all of these principles for designing inclusive online learning is further increased when designing inclusive mobile learning materials. The interface of a learning system presents how does that system look and feel and how does human interact with the system in the process of learning and how does the machine react to human interaction. Hence, while designing the application, it was also taken into account that its user interface should be simple, explicit and intuitive and that navigation within the application should be as easy as possible so that students would not need any particular written instructions or technical skills in order to interact with it (Harrison, Flood, \& Duce, 2013). The aim was that upon entering the environment of the application, students could immediately begin to explore and allows them to discover what they need.

The design of MobiEko app includes Platform Design and System Design which comprise several interactive features, including user profiles, course materials, educational video, self-assessment, quiz, links, portfolio, games, chat, feedbacks and pocket tools. (Fig. 1). The learning material comprises texts, images, and interactive animations. The application runs on Android Operating System and uses AppiePie: a free web-based application that provides varieties 
of modules and components for both Android and Apple platforms. A user has to download and install the MobiEko application onto their mobiles to get the full access to the learning activities. The following table represents the interfaces are design based on the MobiEko modules described in table 1.



Table 1

Interfaces design of MobiEko modules

\begin{tabular}{lll}
\hline $\begin{array}{c}\text { Components/ } \\
\text { Menu }\end{array}$ & \multicolumn{1}{c}{ Modules } & \multicolumn{1}{c}{ Description } \\
\hline Learning menu & $\begin{array}{l}\text { E-notes } \\
\text { Links (website) }\end{array}$ & $\begin{array}{l}\text { Presenting information, providing of- } \\
\text { fline and online learning notes, interac- } \\
\text { tive notes \& link to another website }\end{array}$ \\
\hline $\begin{array}{l}\text { Activities } \\
\text { menu }\end{array}$ & Portfolio & Educational vid- \\
eo & $\begin{array}{l}\text { Preparing teaching and learning } \\
\text { activities, providing individual \& group } \\
\text { activities, discussions \& presentations, } \\
\text { gamification and self- reflections }\end{array}$ \\
\hline $\begin{array}{l}\text { Assessment } \\
\text { menu }\end{array}$ & Self-assessment & $\begin{array}{l}\text { Opportunity to think hard about the } \\
\text { concepts presented in the learning } \\
\text { material and to test his/her understanding } \\
\text { of the topics. }\end{array}$ \\
\hline
\end{tabular}




\begin{tabular}{lll}
\hline $\begin{array}{c}\text { Components/ } \\
\text { Menu }\end{array}$ & \multicolumn{1}{c}{ Modules } & Description \\
\hline & User profile & \\
& Chat & \\
& Feedback & $\begin{array}{l}\text { Provide support for learning activities, } \\
\text { provide learning links \& encouragement } \\
\text { and advice. }\end{array}$ \\
& Learning tips & \\
& Pocket tools & \\
& Survey & \\
\hline
\end{tabular}

\section{ADDIE Framework}

There are various theories and models presented by instructional design researchers, but the ADDIE model is an option in the design of the Microeconomics instructional purposes since the ADDIE model looks closely and system-oriented in producing a good instructional design. Hence this study will focus on the process of how to design and develop a Mobile educational application for Microeconomics course by following the ADDIE theory. To produce effective instruction, all instructional design models require the following phases: analysis, design, development, implementation, and evaluation. These instructional design phases are summarized by the acronym ADDIE, and hence it is now considered a separate model. The ADDIE model (Fig. 2) provides a systematic approach for designing and developing a learning experience. ADDIE is an instructional design model, which is valid for any kind of education and even though ADDIE comprises the components of all other design models it is a relatively simple model (Peterson, 2003). The outcome of each ADDIE phase informs the subsequent phase. The ADDIE model is the most popular model used for designing instruction. It is easy to follow and provides a simple structure. Educators with different instructional design experience can use the ADDIE model to guide the development of their instructions. One commonly accepted improvement to this model is the use of rapid prototyping. This is the idea of receiving continual or formative feedback while instructional materials are being created. This model attempts to save time and money by catching problems while they are still easy to fix. 




The first phase of the ADDIE model is the analysis phase that includes the analysis of the learner needs, context and instructional materials conducted to define the intended learner characteristics like their prior knowledge attitudes, culture and interests, and decide on instructional goals to be achieved. The second phase is the design phase that consists of the identification of learning objectives decided together with the delivery methods, types of learning activities and different types of media. Whereas, the third phase is the development phase that includes the production of instructional contents, a prototype and assessment instruments. Likewise, the fourth phase is the implementation phase that provides support for learners by delivering the instructional materials. The last phase is the evaluation phase that consists of formative and summative evaluation. Formative evaluation refers to the evaluation which occurs during the development phase of ADDIE model, while summative evaluation refers to the evaluation at the end of ADDIE model process (Branch, 2010). As a result, ADDIE model helps the instructional designer with simple and easy to use framework during the design of the instruction (Khalil \& Elkhider, 2016). The ADDIE model is a major instructional model of instruction that is used as the basis and guidance in designing and developing instructional learning materials. The ability of the model to provide a systematic and easy-to-work process framework is easy to follow. 


\section{METHODOLOGY}

This study was conducted to develop an educational mobile application for Microeconomics by eliciting learning content and evaluating learners' satisfaction after the use an app. The design and development of an application prototype in this study are based on the ADDIE instructional design model. The ADDIE (Analysis, Design, Development, Implementation, and Evaluation) instructional design process is a common approach widely used in the development of instructional courses and training programs. This approach provides educators with useful, clearly defined stages for the effective implementation of instruction. The ADDIE framework is a cyclical process that evolves over time and continues throughout the instructional planning and implementation process. The figure. 3 below refers to the conceptual framework based on ADDIE model to describe the design and development of MobiEko application.

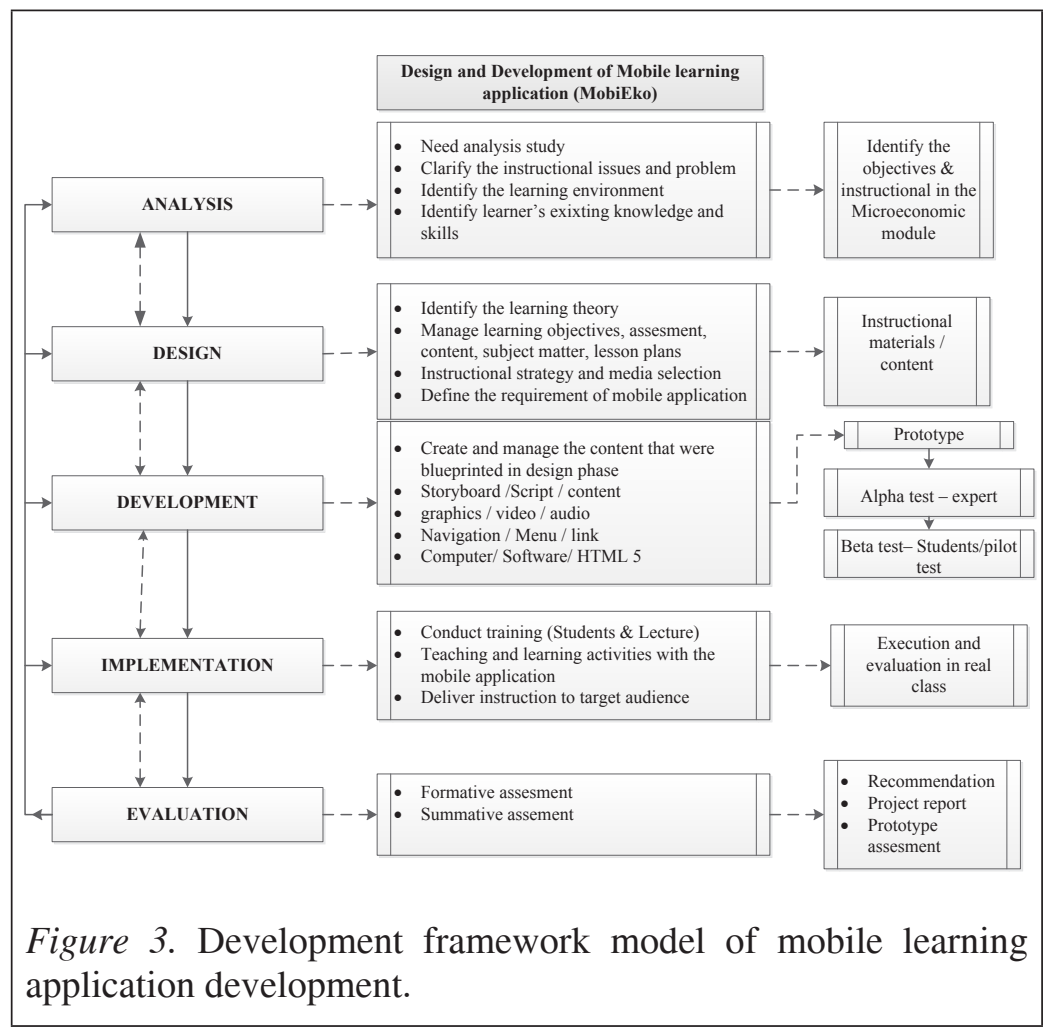


Analyze phase - This step is the description process of what is going to be taught and forms the basis of all other steps. In this step, the designer determines the needs and the difference between knowledge, skills, and behaviors, which the learners presently have, and behaviors which they must have or they are expected to have. In other words, needs analysis is conducted. The system is analyzed and the problem and the roots of the problem are described. To outline the problem, the subject field and the target group were determined in the Analysis phase of the mobile educational application developed according to the ADDIE Design Model. The subject field was Microeconomics class and the target group was selected as firstsemester Polytechnics students from Accounting programme. The target group examined the features of design and development of a mobile application including pre-learning, the degree of readiness concerning the subject and use of technology. Examining the target group as for these features guided the determination of the content and the design of the mobile educational application (presentation, interactivity, visual, navigation and accessibility). By taking into consideration that there are not many technologies based materials available, it was decided that the prepared educational application can be used for different purposes to ensure that the students can practice and review materials at their own learning pace as well as compensate for insufficient learning which occurred during the course.

Design phase - In this step, the development strategy is determined in accordance with the data obtained during the analysis phase and how the objectives will be reached is clarified. In other words, it is the part where the instruction method, learning theories, learning objectives and activities, lesson plans, instructional strategy, and media selection become clear. During the design phase, it was discussed how to teach the subject field by taking into consideration the features of the target group. Thus, the acquisitions concerning the subject in the instruction program were determined. The acquisitions concerning the subject of Microeconomics were included as follows; (i) provides information on concepts, basic principles, and related problems, (ii) emphasizes the demand and supply theory, elasticity and production as well as market equilibrium, (iii) provides information on output level determination and market price structure. It is, therefore, necessary to think about the content of these acquisitions and to develop appropriate instructional methods, 
learning strategies, learning activities and evaluation processes. It was decided that the environment, would be prepared according to the determined acquisitions. Furthermore, discussion and interaction environments would be created to encourage the students to exchange ideas; to ensure communication between students; to give the control to students and; to give a guiding role to the teacher during the process. The content was formed as well as the general framework of the design (for example the screen design, interface, navigation, and accessibility) was developed. The references, where the subjects chosen for the content design are included, were reviewed and the content concerning all the main topic for Microeconomics subject was determined.

Mobile application design also incorporated the tutorial elements such as introduction, concepts, examples, exercises, and a summary to achieve deeper learning objectives. Activities design to be carried out to achieve the objectives of MobiEko should be able compelling students, provide relevant knowledge, help students to understand clearly with the objective of learning, organize content, explain the concept, present the concept in many ways, provide a meaningful exercise, provide sufficient exercise, make sure the example is relevant to the context, create a closure and able to promote discussion. All these elements have long been practiced in the formal learning, and make it " automatically ' through mobile device system will further enhance the ability to learn (Quinn, 2011). Other than that, the application of mobile learning communication functions such as chat, email, push notification, discussion forum, and interactive self-practice materials are also provided to support learners' engagement (Azemi, 1997).

\section{Development Phase}

This is the process of producing the instruction materials, all the tools which will be used during instruction and any kind of support materials. The product is created during this phase and an evaluation, which is mostly for correction, is made and modifications are carried out if necessary. The detailed plan prepared during the phases of analysis and the design is implemented and all the components of the learning environment are developed and the environment is prepared for the test. 
Based on the learning objectives and structure determined in the analysis and design phase, an education application was developed. Development of mobile applications requiring hardware and selection of the right authoring tools. Authoring tool refers to the essential components required in the development of software applications such as audio, video software, graphics, animation and mobile application development software such as Android developer tools (ADB) or through the online based software. In this study, the researchers applied Appy pie software which is one of the top online software available on the Internet for developing mobile applications. The software can support the application process either through the Android platform, Mac OS, Windows Phone, Blackberry, and HTML 5.

For the purpose of uploading the contents of the application, an Internet connection is required to access the server (https://snappy. appypie.com/user/app/user/5fff4f86d579). The server stores all content images, graphics, text, audio, and video for the needs of the application. Display application can also be accessed on the web at the address: http://snappy.appypie.com/html5/MobiEko-1. Meanwhile, the hardware required is as complete sets of computers with the operating system, memory, disk space, processor micro and macro, graphics cards and other appropriate specification. MobiEko is made up of the mobile-server broadcasting sub-system to share data or resources to all mobile devices connected to the server where all activities for blended learning, collaboration, social networking, and learning assessment are carried out. The physical structure MobiEko consists of the learning centre, client, and the server.

After developing the prototype, pre-implementation (pilot test) was carried out in order to test the developed MobiEko application. The study group for the evaluation of the pre-implementation test was composed of 39 students from a first-semester class. The students examined the mobile educational application which was conducted in a classroom. At the end of pre-implementation, a Likert scale questionnaire and open-ended questions were applied in order to get the thoughts of students on the application. Moreover, researchers observed the students while they were carrying out the implementation and took necessary notes and tried to determine where they had difficulty while using the mobile application or where they had not understood. 
Different evaluation forms also were given to the expert judgment as well as the Microeconomics lecturers in order to obtain their thoughts on the mobile application features. Expert judgments gave their recommendations after examining the application. Among the recommendation was to incorporate multimedia elements such as the use of learning videos, graphics, navigation and the use of social media to support discussions through social interaction. In the evaluation form, lecturer stated that they considered the mobile application as positive because it ensured that students are enjoying themselves in the mobile environment. However, the lecturer also gave the ideas such as to include the entertainment and games element to the application. As a result of all the data, the necessary corrections were made for the real implementation.

\section{Implementation Phase}

The implementation phase is the actual use of the learning experience. Regardless of whether the end user will be in the classroom or outside of the class hour, it is necessary to put the design into practice with the actual learners. The purpose of this part is to introduce the designed instruction in a way that it will be effective and efficient. During this phase, the students should be supported to ensure that they understand the material and they are aware of the objectives and there should be no doubt that the information is being transferred to the learner.

The use of prototyping can be used in the classroom or outside the classroom by exploring activities that are available in prototypes such as access to the notes section, quizzes, discussion material, and reflection. The first prototype of MobiEko is an Androidbased operating system application. As described in the design phase, the entire system consists of the clients (Android supported mobile device), system administrator, database and the server. After developing the application, the prototype tested severally on the emulator and actual devices to check the functionality of the different devices. Then, the prototype (MobiEko apps) installed on the real mobile device for debugging. The testing was done on 5.5inches Xiaomi Redmi Note 2 and 5 inches Huawei Honor 3 phone.

The system was implemented according to stakeholder's requirement specifications. Rigorous fine-tuning and iterative features of ADDIE 
were used to arrive at this prototype. The first version of the application was implemented for Android operating system clients. In subsequent versions, popular operating systems such as iOS, Windows will be implemented. The apps can be accessed through a link provided @ http://bit.ly/2ebojLG and downloading MobiEko application is free and requires registration by users.

After the pre-implementation, according to the feedback of students, lecturers, and expert, the problematic or missing parts of the mobile educational application were reviewed and as a result of all the modifications, the mobile application was prepared for the real implementation. The real implementation was carried out with 60 first-semester students. During the implementation process which was conducted in a classroom, first, the pre-test was given to students then they passed to implementation process. This procedure was carried out for all classes 8 weeks. Researchers acted as the assistant for each class. The post-test was applied in an appropriate class hour following the implementation. The results collected from the preand post-test, such as the right or wrong answers that the students gave, guided the review of the mobile instructional application.

\section{Evaluation Phase}

The last major step in the process is the evaluation phase. Evaluation can happen at any stage of the instructional design process. There are two types of evaluation carried out to applications, namely formative and summative assessment. The formative evaluation aims to increase and improve the effectiveness of instructional materials that have been designed. Therefore, the formative evaluation occurs at every level stage starting from the need analysis stage to the implementation stage to ensure the effectiveness of mobile learning applications. At the stage of development, when the prototype has started distributed, the Alpha and Beta test conducted. The Alpha test involves a group of experts engaged to obtain feedback concerning the prototype while Beta test involves the use of prototype among the students who use the application.

As a result of the implementation phase, in order to evaluate the mobile educational application (MobiEko), the effect of the application on achievement levels was examined. The data from the pre-and post-tests was used and a t-test was used for related 
samplings. The results are presented in Table 2 which shows the difference between the pre-test and post-test is considered to be meaningful $(\mathrm{p}=.000)$.

Table 2

Pre- and post-test scores

\begin{tabular}{ccccccc}
\hline & $\mathrm{n}$ & Mean & $\mathrm{sd}$ & $\mathrm{df}$ & $\mathrm{t}$ & $\mathrm{p}$ \\
\hline Pre-Test & 60 & 51.5 & 13.8 & 59 & 37.1 & 0.00 \\
Post Test & 60 & 78.2 & 16.3 & & & \\
\hline
\end{tabular}

In the literature, similarly, Zin, Zaman, \& Noah, (2009) and Yang \& Tsai, (2010) within the scope of Mathematics lesson found differences between pre and post-test scores in the educational application they implemented. These results indicated that integrating technology into teaching and learning may promote students' positive effect on attitudes towards learning. Results of the researchers (Delgadoalmonte, Andreu, \& Pedraja-rejas, 2010; Martin \& Ertzberger, 2013; Norazah Nordin, Sham Ibrahim, Zamri Mahamod, \& Mohd Izham Mohd Hamzah, 2009) shows that the students' improvement increased, positive attitude and better knowledge and skills. The meaningful difference between the pre- and post-test results can be explained by the positive effects of the educational application learning environment on students, which was also observed by the researchers during implementation.

What are the opinions of students on the Mobile application presentation, visual, navigation and accessibility design environment which was developed according to ADDIE design model?

The opinions of students which were collected through multiple choice questionnaires, were examined and are presented in Table 3, 4,5 and 6.

Looking at Table 3, it is clear that most of the students expressed a high level of agreement on the presentation aspect of a mobile application. The item "content structure is well organized" and "the main menu system is easy to use" has the highest number of 
Table 3

Result of the 'Presentation' design analysis

\begin{tabular}{llcc}
\hline No & & \multicolumn{2}{c}{ Presentation (n=76) } \\
\hline & & Agree (f) & $\%$ \\
1. & Interesting screen design. & 60 & 78.9 \\
2. & Content structure is well organized. & 67 & 88.2 \\
3. & Smooth transition from one display to another. & 56 & 73.7 \\
4. & In-app icons are user-friendly. & 62 & 81.6 \\
5. & The main menu system is easy to use. & 67 & 88.2 \\
& - Total average & $\mathbf{6 3}$ & $\mathbf{8 2 . 1}$ \\
\hline
\end{tabular}

"Agree" answers with the percentage rate 88.2 respectively. When examining the opinions of students on "screen design and screen transition", it can be seen that "agree" answer has a considerably high rate of $78.9 \%$ and $73.7 \%$ respectively. This shows that students generally accept the element of presentation on a mobile educational application developed. Concerning if the "app icon is userfriendly", $81.6 \%$ of the students said "agree". It emerged during the observations that the students enjoyed the use of mobile application very much. The icons that are built will make it easy for students to access learning activities according to their needs. Therefore, Wong, Khong, \& Chu, (2012) have recommended designing a successful mobile app, an attractive aesthetical visual of user interface design is the first gateway to attract users to download. Having an enhanced usability and seamless user experience for the targeted users will add to the success of the app.

Table 4

Result of the 'Visual' design analysis

\begin{tabular}{llcc}
\hline No & & \multicolumn{2}{c}{ Visual $(\mathbf{n}=\mathbf{7 6})$} \\
\hline & & Agree (f) & $\%$ \\
1. & The main icons are placed in the area easily & 67 & 88.2 \\
& accessible. & 71 & 93.4 \\
2. $\quad$ The graphics used in this app are appropriate & & (continued)
\end{tabular}




\begin{tabular}{lllc}
\hline No & & \multicolumn{2}{c}{ Visual $(\mathbf{n = 7 6})$} \\
\hline 3. & Use of appropriate colours. & 68 & 89.5 \\
4. & $\begin{array}{l}\text { The composition of this application is orga- } \\
\text { nized. }\end{array}$ & 72 & 94.7 \\
& $\begin{array}{l}\text { The interface display of this application is } \\
\text { user-friendly. }\end{array}$ & 72 & 94.7 \\
& $\quad$ - Total average & $\mathbf{7 0}$ & $\mathbf{9 2 . 1}$ \\
\hline
\end{tabular}

As can be seen in Table 4, 92.1\% of the students stated that they agreed on all the elements of visual design carried out in the mobile application environment using such statements as "main icon easily accessible.", "graphic and colors appropriate.", "composition and user-friendly interface". Overall, all the elements in the visual design recorded high percentage scores. The item "composition of this application is organized " and "user-friendly application interface" respectively recorded the highest percentage score of 94.7 percent. When the students' opinions are examined concerning whether the developed mobile learning application "use an appropriate graphic, colors and easily accessible icons", it can be seen that it has the considerable rate of "agreement" of the whole questionnaire with a rate of $93.4 \%, 89.5 \%$, and $88.2 \%$ respectively. Visual media, such as films, videotapes, TV, and even mobile phone, have the advantage of being easy to deliver in the most classroom or online environments and are inherently interesting to the current generation of students. In addition, because many visual media are temporal and active, rather than static, they can be used to show change and dynamic qualities, which can be especially useful in teaching the sciences or even dance. In the study conducted by Salemi \& Walstad, (2010), it was found people learn abstract, new, and novel concepts more easily when they are presented in both verbal and visual form.

\section{Table 5}

Result of the 'Navigation' design analysis

\begin{tabular}{|c|c|c|c|}
\hline \multirow[t]{2}{*}{ No } & & \multicolumn{2}{|c|}{ Navigation $(n=76)$} \\
\hline & & $\begin{array}{c}\text { Agree } \\
\text { (f) }\end{array}$ & $\%$ \\
\hline 1. & Able to choose any icon for learning activity. & 67 & 88.1 \\
\hline
\end{tabular}




\begin{tabular}{llcc}
\hline No & & \multicolumn{2}{c}{ Navigation $(\mathbf{n}=\mathbf{7 6})$} \\
\hline 2. & $\begin{array}{l}\text { Students have control to determine their learn- } \\
\text { ing activities. }\end{array}$ & 68 & 89.5 \\
3. & $\begin{array}{l}\text { Content delivered facilitates learning. } \\
\text { 4. }\end{array}$ & 69 & 90.8 \\
& $\begin{array}{l}\text { Students are easy to get in and out of the app as } \\
\text { needed. }\end{array}$ & 71 & 93.4 \\
5. & $\begin{array}{l}\text { Interface layout is sorted by category for easy } \\
\text { exploration. }\end{array}$ & 71 & 93.4 \\
& $\quad$ - Total average & $\mathbf{6 9}$ & $\mathbf{9 1 . 1}$ \\
\hline
\end{tabular}

Result analyses from table 5 revealed that most students reported having positive attitudes towards the integration of navigation element in the mobile application developed. Nearly four-fifths of the students felt that the content delivered able to facilitates learning activities (90.8\%), easy to get in and out with the app (93.4\%) and easy exploration (93.4\%). Moreover, $88.1 \%$ student felt that they are free to pick any icon for learning activities and $89.5 \%$ indicated that they able to control the learning activities. In general, navigation within the application was found to be very easy. De Villiers, (2007) have also emphasized in the study they carried out the concerns were raised regarding some aspects of control and navigation. Where pedagogically appropriate, linear sequences should be supplemented with hyperlinked access. Exit and re-entry facilities are required. User-control should be provided over the level of difficulty, so that users can choose particular exercises. This would facilitate different ways of usage at different times.

Table 6

Result of the 'Accessibility' design analysis

\begin{tabular}{|c|c|c|c|}
\hline \multirow[t]{2}{*}{ No } & & \multicolumn{2}{|c|}{ Accessibility $(n=76)$} \\
\hline & & Agree (f) & $\%$ \\
\hline 1. & Access to content learning menu is fast & 52 & 68.4 \\
\hline 2. & This mobile app is easy to install. & 58 & 76.3 \\
\hline 3. & App menu icons are working properly. & 57 & 75.0 \\
\hline 4. & $\begin{array}{l}\text { This app can be utilized to get additional } \\
\text { information. }\end{array}$ & 62 & 81.6 \\
\hline \multirow[t]{2}{*}{5.} & Users are free to explore the app at any time. & 66 & 86.9 \\
\hline & - Total average & 59 & 77.6 \\
\hline
\end{tabular}


The table above shows a percentage of accessibility element in the mobile application. Majority of students expressed a high level of agreement (86.9\%) on item 4 "free to explore the app at any time". It shows that mobile application can transcend the barriers between in-class and out-of-class experiences with opportunities for anywhere anytime learning and the potential for students to participate in educational activities beyond the limitations of the traditional study. Concerning if the developed mobile application can be utilized to get additional information, $81.6 \%$ of the students said "yes". This result shows that the application can be used to help the students find out any additional information related to their learning needs. Additionally, $76.3 \%$ of students agreed that the mobile application developed is easy to install and $75 \%$ felt that the menu icons working properly. In contrast, a low percentage (68.4\%) was recorded on the aspect of content learning access. It appeared during the observations that some of the students not able to access the learning content due to the phone compatibility issue. Different devices may have similar or different accessibility features. Therefore, the instructor has to ensure every student will benefit from the devices at hand or else equal alternatives for those unable to maneuver the technologies should be provided Bidin \& Abu, (2013).

\section{PROTOTYPE}

The developed "MobiEko" smartphone app was designed to be userfriendly. Touching the startup screen makes the main menu appear. The mobile application is developed by dividing the content of the application into four main activities namely as learning menu, learning activities, assessment activities and support activities (table 1). The learning menu consists of offline notes, online notes and main chapter for every topic while learning activities provide activities like problemsolving, tutorials, portfolio, video, and gamification incorporated for strengthening and enrichment elements. For the assessment activities, the MobiEko application integrate quizzes, test and past year test (archive) so that student able to review and exercise the quizzes and test. Lastly, the support section provides the additional activities that can support learning as an enrichment and reinforcement activity for students. Among the activities provided in the support section are information, chatting section, feedback and reflection, appointment, tips and pocket tools. Meanwhile, the log in menu, home menu and some features of MobiEko application are shown in fig.4. 


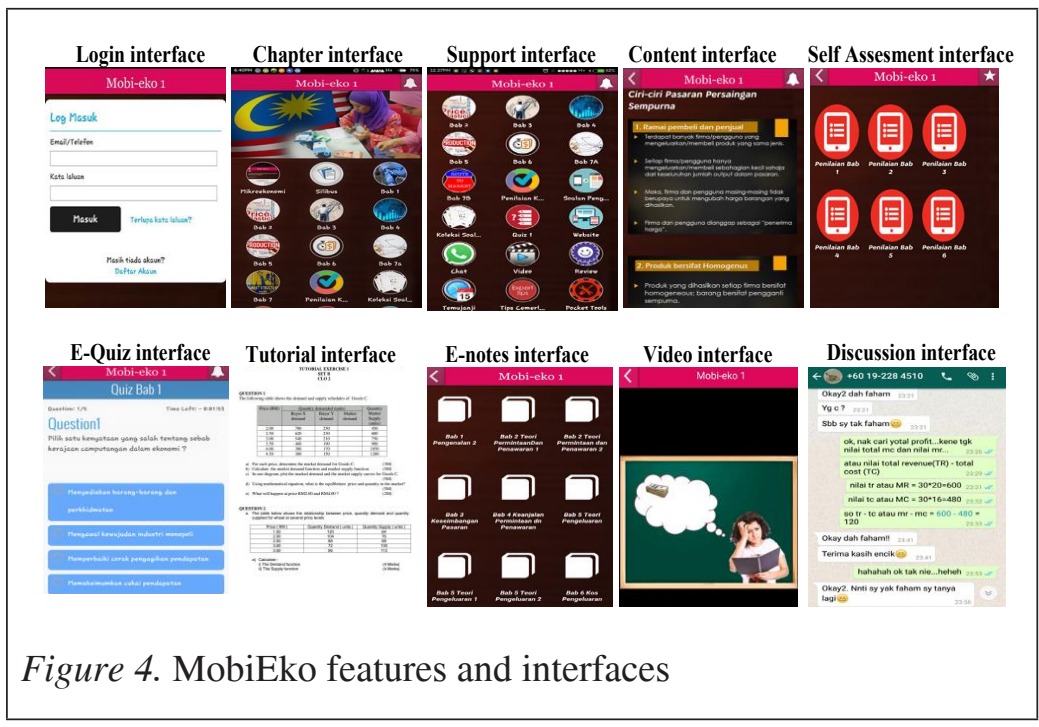

\section{MOBIEKO APP - ENHANCED PEDAGOGICAL LEARNING PROCESS}

Mobile learning is varied from traditional electronic learning; thus, the conventional pedagogical theory should be revised to fit the characteristics of mobile environment. The enhanced pedagogical learning process is utilized to facilitate the learning in mobile learning activities environment. For example, to engage students in economics study and increase their learning efficiency, there are embedded of various activities provided in MobiEko application such as interactive communication, In-App functions, external links, gamification platforms, video and animation, social media and multimedia contents. These educational application materials are planned for a mobile app with short contents, more graphical and small in size play important roles in teaching and learning. Flexible Contents for mobile devices and have a significant positive influence on learning efficiency and understanding through student's engagement into class discussions and help to ease the misconceptions. Additionally, mobile learners nowadays are swipes and tappers, and therefore the design of MobiEko application takes into account on a mobile-centric user interface and user experience that relies on typing, clicking, and browsing.

The Mobieko application is a complete learning aid application that covers the entire learning activities, knowledge, and key concepts 
delivered in form of simple graphical and visual form. The barriers to studying the difficult concepts are also reduced by friendly and colorful graphics. Students can learn as much as they want based on the given knowledge base. They can also extend the readings when they find it interested. To deliver equal access to those developed teaching materials for the students who use different mobile devices or without a mobile device, the teaching materials (MobiEko app) are also adopted in a web-based platform. These embedded activities can be used for class discussion and tutorial or as part of exam questions that help students understand some complex materials or process. A study conducted by Zhang \& Hu, (2015), showed that the use of mobile application materials has positive influence on their learning, which corrected misconceptions, engaged them into discussion, engaged them in Economic study, helped on better understanding, increased learning efficiency, increased long-term memory, and increased overall performance in the adopted subjects. Students also indicated that the adoption of these materials made them interested in the subject study.

The project is designed as a flexible framework for teaching materials, which is easily updated or expanded into other disciplines if needed. Any mobile device that supported multimedia materials can be used in this application, such as video, audio, picture, weblink, and text. Structured conceptions are saved on a database (DB) server and can be downloaded into mobile devices as a standalone data source. The content server is on a cloud web server (appy pie). Data can be updated by editor anytime through internet upload. The multimedia materials are saved on a stream server. The application also provides web access to external links or online video providers such as Youtube. End users can update their database by downloading new content from the servers anytime and anywhere.

To facilitate an efficient learning, functions, and contents activities are designed in a simple format. Each conception in this program consists of a definition, multimedia materials, formula, case studies, or external links that can be accessed easily through. These materials can be learned shortly compared with the text case study in the economic textbook, the efficiency of learning is greatly improved. Moreover, the concept of content delivery is based on the concept of bite-size nuggets. Learning content needs to be packed into small nuggets to engage students on their phones. The key here is "micro 
progress," giving users the satisfaction of completing a task that is part of a larger scope and sequence in one sitting with their mobile device. MobiEko educational app is a great tool for giving students "bite size" of learning that they feel compelled to consume every day. For many learning activities, students will get better simply by investing more time practicing and can be two times more engaged if they can learn from their mobile devices.

The following are some more advantages of getting students with the use of mobile educational application through MobiEko app:

1) Collaborative learning - The mobile app is something that modern students use on a daily basis it is likely to better engage students and promote adoption. The strengths of the MobiEko app are that it is based on collaborative learning, practical (easy to use), and is compatible with modern students' use of technology. These strengths should encourage adoption and acceptance with both academics and student cohorts. By incorporating mobile devices and mobile educational application in the classroom, the process of learning such as discussions, exchanging notes, checking facts, seeking elaboration and other information-gathering activities can be done using their mobile devices as research tools during projects and group work (Rogers \& Price, 2005). Students will not only have access to information during class hour but also can look up information from anywhere on campus. Plus, students love technology so they are likely to be excited about it and continue learning outside of school hours (Gikas \& Grant, 2013; Pimmer, Mateescu, \& Gröhbiel, 2016). Having those learning apps, allows them to get in extra studying and learning in during downtime. They can carry their books and notes with them at all times and have instant access to materials.

2) Accelerated development - Possibly, one of the leading benefits of a MobiEko app with quality educational content is how much mental development it can bring about. The way a student understands and processes information will vary depending on their learning styles. The incorporation of MobiEko app which can facilitate their learning style whilst taking into consideration the curriculum requirements will accelerate the learning process (Cruz, Y., Boughzala, I., \& Assar, 2014). This further emphasizes how an app with 
quality and various content of the specific subject or module can help a learner obtain their goals much quicker. Having mobile devices and mobile application in the classroom allows students instant access to the latest news, information, statistics, etc. Virtually every question they have is at their fingertips, keeping them connected with what's going on around them and ensuring they are always well informed with the most up-to-date information.

3) Efficient education - The activities provided such as case study and problem-solving skills are important. The design of an app with quality content may challenge a learner's problem-solving skills with mobile materials that will motivate them to persist and continually develop themselves in the process (Lefoe, Olney, Wright, \& Herrington, 2009). Learners will become more active in communication and learn much better when they own the learning tool as they consider it useful (Wijtmans, van Rens, \& van MuijlwijkKoezen, 2014). During the learning process, the students worked in teams to analyze and discuss by using mobile devices. The instructor can timely guide students to complete their practice. Meanwhile, by using teamwork, the students make plans accordingly, collect the required information, and make decisions simultaneously.

4) New Learning Methods - The introduction of applications in the education sector has led to the introduction of new learning methods (Herrington, Herrington, Mantei, Olney, \& Ferry, 2009). There are various activities provided for the user such as gamification through kahoot and quizizz, video on demand, tutorials and drill activities available on MobiEko applications that indulge the students into a healthy thought process and help them understand things from a different perspective. Mobile learning application (MobiEko) will guide and assist students in mastering the topics of Microeconomics. The topics developed are in line with the curriculum content outlined by the curriculum Polytechnic. Also, it is expected that the presence of this mobile application can help students revise certain topics according to their abilities and their academic level. Furthermore, by using the application, students can comprehend their level of understanding of each topic and more importantly students can learn on their own at anytime and anywhere (Mehdipour \& Zerehkafi, 2013). This 
will give escalation to a sense of responsibility to the students about what they want to learn and to upsurge the motivation to make the application of motivation using the application.

5) Staying connected - Educational apps are the best way for students to stay connected with their instructors. The previous study showed that the use of educational applications in education has been shown to be effective in enhancing students' learning experience; relevant as an emergent method of modern learning and, met with positive student attitudes and perceptions in terms of adopting and using such technology for educational purposes (Teri et al., 2013). Though the way of learning through apps is entirely different from the traditional learning method, it adds value to the entire process. MobiEko app is available for teachers to support activities in the classroom as teaching aids and support material. There are many activities that can be performed separately or collectively. Furthermore, the instructors also do not need depends only on $\mathrm{CD}$, courseware or textbooks simply because the content of the application meet the syllabus outlined by the Polytechnic Curriculum. In this regard, the application can be used if the teacher is not in the class for whatever reason. Therefore, the student's time will be filled with beneficial activities to ensure that students can take advantage of the application. Thereby, apps are available to student anywhere, anytime and learning will not be confined to the classrooms alone (Hulme, Traxler, \& Pettit, 2007). By using mobile device and MobiEko application, students can really personalize and diversify their learning processes, and all tasks can be rapidly completed in real time.

6) Personalization education - In the modern society, the traditional fixed learning does not meet the needs of learners, but in a mobile education, learners can choose learning time, place, and content according to their own needs; learning progress can also be self-paced and depends on selfdetermination, to realize the individualized learning. Although traditional in-class learning is a method of authentic learning, it is difficult for the teacher to provide full personalized learning support to every student, especially when a large number of students are gathered in the same class (Khaddage \& Knezek, 2011). Che Ku Nuraini \& Faaizah, (2015) pointed out that the personalization learning has strong implications 
for autonomous learning. High levels of personalization would mean that the learner is able to enjoy an authentic learning, action learning, and experiential learning, leading to a strong sense of ownership. In independent learning environments, the instructor and students all could use the MobiEko application feature to record and re-watch videos; collaborate, exchange ideas and relevant documents and files were uploaded. Then, utilize the Internet enables students to view and shared information; these both increase the level of interaction among students, making the learning process enjoyable because students can share information and communicate with each other.

Learning is no more a passive activity, it's active with applications. Therefore, the lessons transforming to mobile activities can change the face of education. The above-mentioned benefits are enough to prove the worth of the educational apps, but the apps have a lot more to offer. Without any doubt, technology has helped a lot to create a global platform for education as well as helped to identify the hidden skills and talents of the students. Thus, educational apps contribute to the learning process and can reshape the future of education.

\section{DISCUSSION}

Based on the findings of the study, a mobile educational application for learning Microeconomics successfully developed based on the ADDIE instructional design model. The application was designed and developed as an effort to make teaching and learning of Microeconomics concepts more interesting and enjoyable for teachers and students. In this study, the ADDIE model was found to be suitable and effective for use in the development of the prototype. Furthermore, researchers must use a suitable model and ensure that the learning materials achieve their development target. Many studies proved that the use of ADDIE model in the design and development of instructional materials (Cho, Sim, \& Hwang, 2014; Nazatul Aini Abd Majid, Mohammed, \& Rossilawati Sulaiman, 2015; Yahaya \& Salam, 2014). Results of this study indicate that the ability of ADDIE model to provides designers and educators with useful, clearly defined stages for the effective implementation of instruction. 
When it comes to the opinions of students on the Mobile application design in terms of presentation, visual, navigation and accessibility, it is clear that most of the students expressed a high level of agreement on the design aspect. The findings that indicate that the importance of interface design and attention to usability will lead to better mobile learning and well-designed educational apps are very effective for students learning. These results are in line with the results of several other studies employed user interface design (Harrison et al., 2013; Tahir \& Arif, 2014). Therefore, mobile educational applications are extremely useful for learning experiences of students and the user interface (UI) design of these applications is a key concern for their success and usefulness.

The current study contributed to the literature in that using mobile applications in Economics teaching and learning can be a more effective tool when compared to traditional paper-based activities. The benefits of educational materials using smartphone apps are that they allow users to have an instant access to educational data and to enjoy the freedom of mobility in places where there are no computers available at any time learners need them. For example, individuals could download educational contents into a local database on their mobile device and access the data directly, giving them greater levels of freedom. Moreover, mobile devices offer multimedia services, and a wide variety of interesting and engaging applications have already been developed for them, such as PIM (Personal Information Management), GPS, camera, and games. Therefore, the "MobiEko" application, which was developed to address such issues, will play an important role as a private electronic textbook for Microeconomic students. The findings support assertions made by researchers (Maslin Masrom, Amirah Syahmi Nadzari, \& Zakaria, 2016; Oyelere, 2016; Raman \& Jambulingam, 2012) that Mobile Learning via mobile devices can assist students to achieve their learning objectives owing to the flexibility of the format for the transmission of knowledge. These findings suggest that there is a potential in utilizing mobile phones to complement classroom learning.

\section{IMPLICATIONS}

The results showed that the MobiEko application produced positive learning outcomes and had a positive impact on students' 
conceptions about Microeconomics. Furthermore, the students reported satisfaction from using the application, which they found the design of mobile instructional is integrated with the presentation, visual, navigation and accessibility design. These findings suggest that mobile educational application, specifically designed based on curricular learning objectives and sound mobile educational design principles, can contribute in the construction of curricular knowledge in core academic subjects such as Microeconomics. Research has shown that educational applications built with good design can increase the motivation to learn, opening up more space for learning either informal or semiformal and have more control over their learning goals (Jones, Scanlon, \& Clough, 2013). Furthermore, these findings have implications for educational software designers and educators in Economics and other curricular subjects. The instructional design and development should incorporate mobile technology elements in their products to making them more effective, engaging and interactive. The future of using technology for teaching economics will be the continuation of recent trends: increased portability in the access to instruction and increased opportunities for interaction, including students' interaction with the material and with the instructor and other students. There is also the possibility of radical change that may fundamentally affect economics instruction in the future.

\section{CONCLUSION}

In this paper, the work-in-progress of MobiEko - an Android version of mobile learning application has been reported. MobiEko educational application is designed as an assisting teaching and learning tool for Economic subjects with a flexible framework. It suits any smart mobile device that supported multimedia materials, such as video, audio, picture, web-link, and text. The concept of mobile learning application seems to be an interesting and mobile educational application have the potential to provide a different and exciting learning experience for users. Therefore, a mobile educational application should be given the opportunity to offer their benefits in the learning process. To ensure the applicable mobile learning application performance and can attract students to learn, MobiEko application developed with an emphasis on noticeable presentation and integrated learning materials. The development 
of the learning materials prepared with carefully guided by ADDIE model so that the content more easily understood and lead to effective learning. Research findings indicate that mobile learning applications (MobiEko) have the potential to provide a different and exciting learning experience for users. The application of mobile technology for learning purposes is boundless, especially because mobile devices are now common amongst students, and the mobile phone, in particular, is the most commonly used device by the majority of students. Most of the previous studies showed a positive impact and encouraging results; mobile education has vast potential implications and benefits especially in life learning.

Mobile educational application (MobiEko) performed as a knowledge transfer channel to help students and learners understand better the concepts and course contents as well as facilitated educators and students with better or more convenient ways in their teaching and learning activities. Technology is a tool for teaching and learning and it should support teaching and learning just like normal chalks and blackboards. A good mobile teaching and learning system should be based on solid knowledge base, proper curriculum design and system design, a good understanding of the students' needs, prompt communication between students and educators, and continuous enhancements and improvement due to proper suggestions and feedbacks. In conclusion, no technology can perform as a good teaching and learning platform without these important elements.

\section{REFERENCES}

Azemi, A. (1997). Developing an active learning environment with courseware approach. Proceedings Frontiers in Education 1997 27th Annual Conference., 3(i), 1179-1184. http://doi. org/10.1109/FIE.1997.632627

Baharom, S., \& Hussain, R. M. R. (2013). An exploration of the mobile learning environment to support teacher training. In Mohamed Amin Embi \& N. M. Nordin (Eds.), Mobile Learning: Malaysian initiatives \& research findings (pp. 103-110). Bangi: Centre For Academic Advancement, Universiti Kebangsaan Malaysia.

Bidin, S., \& Abu, A. (2013). Adoption and application of mobile learning in the education industry. Procedia - Social and 
Behavioral Sciences, 90(InCULT 2012), 720-729. http://doi. org/10.1016/j.sbspro.2013.07.145

Bidin, S., \& Ziden, A. A. (2013). Adoption and Application of mobile learning in the education industry. Procedia - Social and Behavioral Sciences, 90, 720-729. http://doi.org/10.1016/j. sbspro.2013.07.145

Branch, R. M. (2010). Instructional design: The ADDIE approach. Instructional design: The ADDIE approach. http://doi. org/10.1007/978-0-387-09506-6

Che Ku Nuraini Che Ku Mohd, \& Faaizah Shahbodin. (2015). Personalized learning environment: Alpha testing, Beta Testing \& user acceptance test. In Procedia - Social and Behavioral Sciences (Vol. 195, pp. 837-843). Elsevier B.V. http://doi.org/10.1016/j.sbspro.2015.06.319

Cho, M. J., Sim, J. L., \& Hwang, S. Y. (2014). Development of smartphone educational application for patients with coronary artery disease. Healthcare Informatics Research, 20(2), 11724. http://doi.org/10.4258/hir.2014.20.2.117

Cruz, Y., Boughzala, I., \& Assar, S. (2014). Technology accaptance and actual use with mobile learning: First stage for studying the influence of learning styles on the behavioral intention. Twenty Second European Conference of Information Systems, Tel Aiv, 1-16.

de Villiers, M. R. (2007). An action research approach to the design, development and evaluation of an interactive e-learning tutorial in a cognitive domain. Journal of Information Technology Education, 6, 455-479. Retrieved from http:// www.editlib.org.ezproxy.psz.utm.my/p/101768/

Delgado-almonte, M., Andreu, H. B., \& Pedraja-rejas, L. (2010). Information technologies in higher education: Lessons learned in industrial engineering ICTs in education. Educational Technology \& Society, 13(4), 140-154.

Ding, M., \& Li, H. (2011). On the application of multimedia in economics teaching. International Education Studies, 4(3), 2010-2012. http://doi.org/10.5539/ies.v4n3p88

E. Lefoe, G., Olney, I. ., R.Wright, \& A. Herrington. (2009). Faculty development for new technologies: Putting mobile learning in the hands of the teachers. In New Technologies, New Pedagogies: Mobile Learning In Higher Education (p. 18). Universiti of Wolonggong, Australia. 
Elias, T. (2011). Principles for mobile learning. International Review of Research in Open and Distance Learning, 12.2, 144-156. http://doi.org/10.1007/978-1-4419-0585-7

Embi, M. A., \& Nordin, N. M. (2013). Mobile Learning : Malaysian initiatives \& research findings. (M. A. Embi \& N. M. Nordin, Eds.) Centre For Academic Advancement, Universiti Kebangsaan Malaysia. Bangi: Centre For Academic Advancement, Universiti Kebangsaan Malaysia \& Department of Higher Education, Ministry of Higher Education.

Fetaji, M. (2008). Designing usable M-learning application : Mobileview case study. In World Conference on Educational Multimedia, Hypermedia and Telecommunications (EDMEDIA) (pp. 3-8).

Gikas, J., \& Grant, M. M. (2013). Mobile computing devices in higher education: Student perspectives on learning with cellphones, smartphones \& social media. Internet and Higher Education, 19, 18-26. http://doi.org/10.1016/j.iheduc.2013.06.002

Harrison, R., Flood, D., \& Duce, D. (2013). Usability of mobile applications: literature review and rationale for a new usability model. Journal of Interaction Science, 1(1), 1-16. http://doi. org/10.1186/2194-0827-1-1

Herrington, J., Herrington, A., Mantei, J., Olney, I., \& Ferry, B. (2009). Using mobile technologies to develop new ways of teaching and learning. In New Technologies, New Pedagogies: Mobile Learning In Higher Education (pp. 1-15). Wollongong: University of Wollongong, Australia. Retrieved from http://ro.uow.edu.au/cgi/viewcontent.cgi?art icle $=1077 \&$ context $=$ edupapers

Hirsh-Pasek, K., Zosh, J. M., Golinkoff, R. M., Gray, J. H., Robb, M. B., \& Kaufman, J. (2015). Putting education in "Educational" apps: Lessons from the science of learning. Psychological Science in the Public Interest (Vol. 16). http:// doi.org/10.1177/1529100615569721

Hsu, Y. C., \& Ching, Y. H. (2013). Mobile app design for teaching and learning: Educators' experiences in an online graduate course. International Review of Research in Open and Distance Learning, 14(4), 117-139.

Hulme, A. K., Traxler, J., \& Pettit, J. (2007). Designed and usergenerated activity in the mobile age. Journal of Learning Design, 2(1), 52-65. 
Hwang, G., \& Tsai, C. (2011). Research trends in mobile and ubiquitous learning: a review of publications in selected journals from 2001 to 2010. British Journal of Educational Technology, 42(4), 65-70. http://doi.org/10.1111/j.14678535.2011.01183.x

Irwan, I. M., Norazah, M. N., Rosseni, D., Arif, a. R. A., \& Ridzwan, C. R. (2015). Design and development performance-based into mobile learning for TVET. Procedia - Social and Behavioral Sciences, 174, 1764-1770. http://doi.org/10.1016/j. sbspro.2015.01.835

Jones, A. C., Scanlon, E., \& Clough, G. (2013). Mobile learning: Two case studies of supporting inquiry learning in informal and semiformal settings. Computers and Education, 61(1), 21-32. http://doi.org/10.1016/j.compedu.2012.08.008

Joshi, P., \& Marri, A. R. (2006). An economics methods course?: Challenges of teaching an economics education methods course for secondary social studies preservice teachers. The Social Studies, 97(October), 197-202. http://doi.org/10.3200/ TSSS.97.5.197-202

Khaddage, F., \& Knezek, G. (2011). Device independent mobile applications for teaching and learning: Challenges, barriers and limitations. Global Learn 2011, 1-7. Retrieved from http://www.editlib.org/p/37143

Khalil, M. K., \& Elkhider, I. A. (2016). Applying learning theories and instructional design models for effective instruction. Advances in Physiology Education, 40(2), 147-156. http:// doi.org/10.1152/advan.00138.2015

Martin, F., \& Ertzberger, J. (2013). Computers \& education here and now mobile learning : An experimental study on the use of mobile technology. Computers \& Education, 68, 76-85. http://doi.org/10.1016/j.compedu.2013.04.021

Maslin Masrom, Amirah Syahmi Nadzari, \& Zakaria, S. A. (2016). Implementation of mobile learning apps in malaysia higher. In e-Proceeding of the 4th Global Summit on Education 2016 (Vol. 2016, pp. 268-276).

Mehdipour, Y., \& Zerehkafi, H. (2013). Mobile learning for education : Benefits and challenges. International Journal of Computational Engineering Research, 3(6), 93-101.

Nawi, A., Hamzah, M. I., Akmal, S., \& Sattai, A. (2014). Potensi penggunaan aplikasi mudah alih ( mobile apps ) dalam bidang pendidikan Islam. Online Journal of Islamic Education, 2(2), 26-35. 
Nazatul Aini Abd Majid, Mohammed, H., \& Rossilawati Sulaiman. (2015). Students â $€^{\mathrm{TM}}$ perception of mobile augmented reality applications in learning computer organization. In Procedia - Social and Behavioral Sciences (Vol. 176, pp. 111-116). Elsevier B.V. http://doi.org/10.1016/j.sbspro.2015.01.450

Norazah Nordin, Sham Ibrahim, Zamri Mahamod, \& Mohd Izham Mohd Hamzah. (2009). Reka bentuk dan pembangunan pembelajaran atas talian menggunakan sumber terbuka dalam pengurusan dan kepimpinan pendidikan. ASEAN Journal of Teaching and Learning in Higher Education, 1(2), 47-58.

Nordin, N., Amin, M., \& Yunus, M. (2010). Mobile learning framework for lifelong learning. In International Conference on Learner Diversity 2010 (Vol. 7, pp. 130-138). http://doi. org/10.1016/j.sbspro.2010.10.019

Oyelere, S. S. (2016). Design and implementation of MobileEdu m-learning application for computing education in Nigeria : A design research approach. In Learning and Teaching in Computing and Engineering (LaTICE), 2016 International Conference (pp. 27-31). Mumbai. http://doi.org/10.1109/ LaTiCE.2016.3

Peterson, C. (2003). Bringing ADDIE to life : Instructional design at its best. Journal of Educational Multimedia and Hypermedia, 12(3), 227-241.

Pimmer, C., Mateescu, M., \& Gröhbiel, U. (2016). Mobile and ubiquitous learning in higher education settings. A systematic review of empirical studies. Computers in Human Behavior, 63, 490-501. http://doi.org/10.1016/j.chb.2016.05.057

Prensky, M. (2001). Digital Natives, Digital Immigrants. From on the Horizon, 9(5), 1-6. http://doi. org/10.1108/10748120110424816

Prensky, M. (2005). Listen to the natives. Educational Leadership, 63(4), 8-13. http://doi.org/10.1177/0956474806067746

Quinn, C. N. (2011). Designing mLearning: Tapping into the mobile revolution for organizational performance. Pfeiffer, Wiley Imprint. Retrieved from www.pfeiffer.com

Raman, M., \& Jambulingam, M. (2012). Adoption of mobile technology in a learning environment. International Conference on Emerging Trends of Computer \& Information Technology ( ICETCIT 2012 ).

Rio Sumarni Shariffudin. (2007). Design of instructional materials for teaching and learning purposes: Theory into practice. $M E D C, 1$ (December), 97-110. 
Rogers, Y., \& Price, S. (2005). Extending and augmenting scientific enquiry through pervasive learning environments. Children, Youth and Environments, 14(2), 67-83. Retrieved from http:// www.colorado.edu/journals/cye/14_2/article4.htm

Salemi, M. K., \& Walstad, W. B. (2010). Teaching innovations in economics: Strategies and innovations for interactive instruction. Edward Elgar Publishing Limited, MI.

Syer, M. D. (2013). Empirical studies of mobile apps and their dependence on mobile platforms. Queen's University, Kingston, Ontario, Canada. Retrieved from http://hdl.handle. net/1974/7767

Tahir, R., \& Arif, F. (2014). Framework for evaluating the usability of mobile educational applications for children. In Society of Digital Information and Wireless Communications (pp. 156170).

Tajudeen, S. A., Basha, M. K., Fakomogbon, O., \& Mukthar, A. L. (2011). Determinant of mobile devices acceptance for learning among students in developing country, 1(3), 17-29.

Teri, S., Acai, A., Griffith, D., Mahmoud, Q., Ma, D. W. L., \& Newton, G. (2013). Article student use and pedagogical impact of a mobile learning application. Biochemistry and Molecular Education, (Wiley Online Library), 1-15. http:// doi.org/10.1002/bmb.20771

Wang, M., \& Shen, R. (2012). Message design for mobile learning: Learning theories, human cognition and design principles. British Journal of Educational Technology, 43(4), 561-575. http://doi.org/10.1111/j.1467-8535.2011.01214.x

Wijtmans, M., van Rens, L., \& van Muijlwijk-Koezen, J. E. (2014). Activating students' interest and participation in lectures and practical courses using their electronic devices. Journal of Chemical Education, 91(11), 1830-1837. Retrieved from http://pubs.acs.org/doi/abs/10.1021/ed500148r

Wong, C. Y., Khong, C. W., \& Chu, K. (2012). Interface design practice and education towards mobile apps development. Procedia - Social and Behavioral Sciences, 51, 698-702. http://doi.org/10.1016/j.sbspro.2012.08.227

Yahaya, N. S., \& Salam, S. N. A. (2014). Mobile learning application for children: Belajar bersama Dino. Procedia - Social and Behavioral Sciences, 155(October), 398-404. http://doi. org/10.1016/j.sbspro.2014.10.312 
Yang, D. C., \& Tsai, Y. F. (2010). Promoting sixth graders' number sense and learning attitudes via technology-based environment. Educational Technology \& Society, 13, 112125.

Zhang, M., Trussell, R. P., Tillman, D. a., \& An, S. a. (2015). Tracking the rise of web information needs for mobile education and an emerging trend of digital divide. Computers in the Schools, 32(2), 83-104. http://doi.org/10.1080/073805 69.2015.1030531

Zhang, Y. A., \& Hu, J. (2015). Tutors in pockets for economics. In Handbook of Mobile Teaching and Learning (pp. 291-307). http://doi.org/10.1007/978-3-642-54146-9_1

Zin, N. A. M., Zaman, H. B., \& Noah, S. A. M. (2009). Penilaian perisian kursus adaptif multimedia ( A-Maths ) berasaskan stail pembelajaran. Jurnal Teknologi Maklumat, 5, 61-78. 